\title{
PLURALISM AND POLITICAL CONFLICT IN INDONESIA*
}

\author{
Thomas B. Pepinsky
}

\section{Introduction}

Contemporary Indonesian politics is characterized by inequality. Scholars of oligarchy have provided the most cogent analysis of Indonesia's extraordinarily unequal distribution of material wealth as a central feature of Indonesian politics. They have also pushed forward the comparative analysis of national political systems by using the Indonesian case to conceptualize oligarchy as a category of political analysis. ${ }^{1}$ These analyses draw attention to the manifest weaknesses of Indonesian democracy, and highlight the differences between the formal rules and procedures that constitute democracy, and the exercise of power under democratic rule.

Pluralism is an alternative framework through which to analyze Indonesian politics. Pluralism shares with Marxist and other materialist analyses of politics a "socially determinist" ${ }^{2}$ conception of politics. It rejects the position that material interests are fundamentally different from other interests, with fundamentally different consequences for political action. The weaknesses of early pluralist analyses are wellknown: they offered a theoretical framework, not a theory of anything; pluralism as a concept is most fruitfully applied to the static analysis of existing cleavages rather than to the dynamic analysis of where cleavages come from and why they persist or change;

* Special thanks to Michele Ford and Matt Winters for comments on an early draft.

${ }^{1}$ Richard Robison and Vedi R. Hadiz, Reorganising Power in Indonesia: The Politics of Oligarchy in an Age of Markets (London: RoutledgeCurzon, 2004); and Jeffrey A. Winters, Oligarchy (New York, NY: Cambridge University Press, 2011).

2 Theda Skocpol and Kenneth Finegold, "State Capacity and Economic Intervention in the Early New Deal," Political Science Quarterly 97,2 (1982): 259. 
and most seriously, the conception of power (and of interest itself) typically affirmed by a pluralist analysis is one dimensional and reductive. ${ }^{3}$ For these reasons, many recent analyses of contemporary Indonesian politics working outside of the oligarchic tradition have ignored or downplayed their pluralist heritage.

This essay explores the complementarities and the tensions between pluralism and recent analyses of oligarchy in Indonesia. Its goal is to argue that a "critical" pluralism offers a toolkit through which to understand Indonesian politics, as well as a progressive research program that can push the analysis of material wealth and political power further than existing research on oligarchy. This open dialogue between pluralist and oligarchic analyses contributes to the study of material wealth and political power (in Indonesia and elsewhere) in three ways. Conceptually, it helps analysts distinguish between descriptive and causal claims about material wealth, political power, and political outcomes. Theoretically, it challenges oligarchic analyses by offering competing and complementary causal arguments about the effects of the unequal distribution of material resources. Methodologically, it outlines a practice of knowledge production for scholars of Indonesia interested in effects of material wealth on contemporary Indonesian politics, one that invites structured comparison with other national contexts or historical periods and clarifies the role of evidence in adjudicating among contending approaches.

My use of the qualifying term "critical" here is deliberately nonstandard. ${ }^{4}$ Rather than serving as a dogwhistle for structural or materialist theories of politics, it is meant as an internal challenge to theories of pluralism themselves, one that follows from the weaknesses outlined above and seeks to address them by questioning why cleavages exist and why interests are or are not articulated; this enables scholars to move beyond one- and two-dimensional analyses of power and interest, and to take history and social structures seriously. None of these pluralist auto-critiques is original to this essay, yet they have not been articulated in sustained conversation with the empirics of contemporary Indonesia for two decades. ${ }^{6}$ In my usage, "critical" also rejects the search for a single master narrative in Indonesian politics, and recommends a practice of Indonesian political studies that is concerned first and foremost with middle range

\footnotetext{
${ }^{3}$ Steven Lukes, Power: A Radical View, 2nd ed. (New York, NY: Palgrave Macmillan, 2005).

${ }^{4}$ I borrow the term "critical pluralism" from Gregor McLennan, Marxism, Pluralism, and Beyond: Classic Debates and Nezo Departures (Cambridge: Polity Press, 1989), pp. 43-56. Here, McLennan makes passing reference to Robert Dahl and Charles Lindblom's critique of conventional pluralist analyses of the United States political economy. McLennan is also the source of the term "conventional pluralism," as discussed below.

${ }^{5}$ Gabriel Almond has argued that the early pluralist literature was far more conceptually advanced than its later critics have allowed, implying that most of these critiques were actually well understood as early as the 1950s. For a review, see the chapter by Gabriel A. Almond, "Corporatism, Pluralism, and

Professional Memory," in A Discipline Dizided: Schools and Sects in Political Science, ed. Gabriel A. Almond (Newbury Park, CA: Sage Publications, 1990), pp. 173-88.

${ }^{6}$ Stefan Eklöf has observed a general decline of theoretical debate among models of Indonesian politics by the late New Order period: Stefan Elköf, Power and Political Culture in Suharto's Indonesia: The Indonesian Democratic Party (PDI) and the Decline of the New Order (1986-98) (Copenhagen: NIAS Press, 2003), p. 11. This may reflect the exhaustion of these debates, or a general shift from a focus on typological theory to quantitative measurement in comparative politics; see David Collier, Jody LaPorte, and Jason Seawright, "Putting Typologies to Work: Concept Formation, Measurement, and Analytic Rigor," Political Research Quarterly 65,1 (2012): 217-32.
} 
theory in the service of social explanation. ${ }^{7}$ Pluralism, like any other approach to social analysis, is strongest when it recognizes the limits of its explanatory power.

Because pluralism is not a theory that predicts any particular outcome, it cannot be falsified or tested. However, a critical pluralism produces hypotheses in the study of material wealth in Indonesian politics that can be falsified through empirical analysis. Political conflict during Indonesia's financial crisis and local economic governance in decentralized Indonesia offer two topical studies through which to contrast pluralism and oligarchy as explanatory frameworks for key issues in contemporary Indonesian politics in which massive inequalities in wealth feature prominently.

The essay proceeds as follows. It first traces a brief history of pluralist theory in comparative political analysis, and then highlights applications of pluralism to the analysis of Indonesia's political economy in the New Order period. From this review, it will become clear that, much as scholars of United States politics concluded in the 1960s, pluralist analyses of anything approaching "interest-group liberalism" in Indonesia are inappropriate. ${ }^{8}$ From there, I move to a direct engagement with the concept of oligarchy as presented by Vedi Hadiz and Richard Robison and Jeffrey Winters, outlining the points of tension between oligarchic and pluralist analyses. Building on that discussion, I next present the two topical case studies. In each, I begin with what I interpret to be the useful strengths of an oligarchy-based approach to contemporary problems in Indonesian politics, before then introducing the problems that a pluralist critique inevitably raises and the solutions that it provides. The essay concludes by discussing how Indonesianists should build a progressive, cumulative research program ${ }^{9}$ to study Indonesian politics without ignoring the extraordinarily unequal distribution of wealth or its corrosive effects on the functioning of Indonesian democracy.

\section{Pluralism in Indonesian Politics}

The essence of pluralism is a conception of politics as competition among pressure groups that represent various interests in society. ${ }^{10}$ Pluralism has changed significantly

\footnotetext{
${ }^{7}$ Daniel Ziblatt, "Of Course Generalize, But How? Returning to Middle Range Theory in Comparative Politics," American Political Science Association-Comparative Politics Nezusletter 17,2 (2006): 8-11.

${ }^{8}$ The classic statement of this critique in the United States context is Theodore M. Lowi, The End of Liberalism, revised ed. (New York, NY: Norton, 1979).

${ }^{9}$ Here, I mean "progressive" in the standard Lakatosian sense; see Imre Lakatos, "Falsification and the Methodology of Scientific Research Programs," in Criticism and the Growth of Knowledge, ed. Imre Lakatos and Alan Musgrave (New York, NY: Cambridge University Press, 1970): 91-196.

${ }^{10}$ Even though pluralism was a dominant current in the political science mainstream for most of the twentieth century, it was never definitively articulated as a theory of politics by any of the major scholars associated with it. Before the conceptual debate on pluralism and its alternatives declined in the 1990s, in fact, critics commonly observed that pluralism had no core principles upon which its adherents commonly agreed; see Grant Jordan, "The Pluralism of Pluralism: An Anti-theory?," Political Studies 38,2 (1990): 286301; and McLennan, Marxism, Pluralism, and Beyond, p. 35. Commenting on Arend Lijphart's analysis of consociationalism, Gary King, Robert Keohane, and Sidney Verba observe that "it was widely recognized that the concept of pluralism was often used in conflicting ways, none clear or concrete enough to be called a theory. Ronald Rogowski's description of pluralism as a 'powerful, deductive, internally consistent theory' ... is surely the first time it has received such accolades." See Gary King, Robert $\mathrm{O}$. Keohane, and Sidney Verba, "The Importance of Research Design in Political Science," American Political Science Review 89,2 (1995): 480, note 3.
} 
over the past six decades; here, I outline its evolution only briefly. ${ }^{11}$ As originally developed, pluralism had both descriptive and normative ambitions, and was used not only to characterize the nature of political conflict but also to legitimize the practice of democratic life. ${ }^{12}$ Later analyses, led by Robert Dahl (himself a key figure in early pluralist debates), began to separate the descriptive from the normative components of a pluralist analysis of politics. While these scholars remained deeply committed to a normative analysis of democratic politics in capitalist states, ${ }^{13}$ their critical analysis of pluralism as a descriptive framework became more tightly focused on characterizing the essential axes of political conflict within different polities. ${ }^{14}$

While a useful corrective to the most idealistic and unreflective pluralist analyses, Dahl's most critical approach to pluralism did not save this tradition from losing intellectual currency as political scientists transitioned away from paradigmatic debates in comparative politics. Theodore Lowi's critique of "interest-group liberalism" in the United States also helped to bury conventional pluralism. ${ }^{15}$ However, the pluralist impulse to characterize politics and the policymaking process as competition among groups defined by their interests in policy outcomes has survived. This is most apparent in the lineage of Mancur Olson's The Rise and Decline of Nations, which used Olson's earlier writings on collective action and group behavior to explore how distributional coalitions shaped politics and policy. ${ }^{16}$ Here, the break from the normative aspirations of early pluralism is complete, for Olson's analysis was skeptical that "pressure groups" were representative of anything resembling the public interest, and that their competition would have salutary effects on national politics or on economic performance. ${ }^{17}$ Important comparative works following (more or less conspicuously) in this theoretical tradition concerned with distributional politics, in which sectoral and class interests shape politics and policy, include Peter Gourevitch on politics after economic crises, Ronald Rogowski on trade and political alignments,

\footnotetext{
${ }^{11}$ A recent, textbook-style overview of the pluralist tradition and its contemporary successors can be found in John S. Dryzek and Patrick Dunleavy, Theories of the Democratic State (New York, NY: Palgrave Macmillan, 2009), pp. 35-56 and 131-203.

12 The standard reference is David B. Truman, The Governmental Process (New York, NY: Alfred A. Knopf, 1951).

${ }^{13}$ Most notably, see Robert A. Dahl, A Preface to Economic Democracy (Berkeley, CA: University of California Press, 1985).

${ }^{14}$ See, e.g., Robert A. Dahl, "Pluralism Revisited," Comparative Politics 10,2 (1978): 191-203.

${ }^{15}$ Lowi, The End of Liberalism. Andrew McFarlane labels Lowi's alternative as "plural-elitist theory." Distributive and redistributive politics remain essential to this conception of politics and policymaking; see Andrew S. McFarland, "Interest Groups and Theories of Power in America," British Journal of Political Science 17,2 (1987): 129-47.

${ }^{16}$ Mancur Olson, The Rise and Decline of Nations: Economic Growth, Stagflation, and Social Rigidities (New Haven, CT: Yale University Press, 1984).

${ }^{17}$ Harmon Zeigler, "Interest Groups," in Encyclopedia of Government and Politics, ed. Mary Hawkesworth and Maurice Kogan (New York, NY: Routledge, 1992), pp. 377-92. Public choice theory draws on similar insights, but has grown to encompass a general critique of interventionist government as hopelessly captured by special interests; the standard reference is James M. Buchanan and Gordon Tullock, The Calculus of Consent: Logical Foundations of Constitutional Democracy (Ann Arbor, MI: University of Michigan Press, 1962). This "Virginia school" public choice critique of regulation or activist government does not follow logically from a pluralist ontology of political conflict. Olson himself "complained that'the value of the scientific contributions of Gordon Tullock and his colleagues in the Virginia School is obscured when it is treated as a part of or a justification for any right-wing ideology."' See Iain McLean, "The Divided Legacy of Mancur Olson," British Journal of Political Science 30,4 (2000): 657.
} 
and Jeffry Frieden on Latin American political economy. ${ }^{18}$ Distributional politics figures also prominently in later analyses of economic development, economic reform, and public policy, even if business, sector, or factor interests are only partially determinant of these outcomes. ${ }^{19}$

The important conclusion is that the pluralism of mid-century North Atlantic political science has been discarded almost entirely, rendered obsolete by both internal critiques (Dahl) and external critiques, both moderate (Lowi) and radical (Lukes). Pluralism's intellectual heritage survives, however, in the analysis of distributional politics. My understanding of pluralism as applied to contemporary Indonesian politics begins from the perspective that political actors engage in politics to produce policies that they favor. Political conflict results from differences in the interests of various actors, both individuals and groups. Political outcomes are shaped by the resources available to conflicting groups and the institutions that aggregate or channel individual or collective preferences. These institutions are themselves subject to manipulation by the actors and groups whom or which they are meant to constrain, such that conflict about political institutions reflects more basic conflicts over distribution, redistribution, and recognition. There is no reason to believe that such conflict will always produce balanced or socially optimal policy outcomes, that "interest groups" as conventionally understood always exist, or that the recognizable interest groups that do exist are representative of the interests that they may claim to represent.

\section{Modified Pluralisms and the New Order Political Economy}

Conventional pluralism was never a serious analytical framework for Indonesian politics. However, pluralism did shape the research agenda on the New Order. The problem was how to square the observation that Suharto's regime faced no significant threat from any organized opposition group with the observation that it was possible to uncover clear evidence of distributional politics with effects on policy outcomes; in areas ranging from financial deregulation to rice and sugar policy, relatively weak groups and interests were able to shape policy outcomes in their favor, and executive preferences rarely determined policy outcomes alone. ${ }^{20}$ The search for pluralism in New Order politics was reinforced by parallel currents in the study of communist Europe, which sought to demonstrate the utility of a pluralist conceptual framework

${ }^{18}$ Jeffry A. Frieden, Debt, Development, and Democracy: Modern Political Economy and Latin America, 19651985 (Princeton, NJ: Princeton University Press, 1991); Peter Gourevitch, Politics in Hard Times: Comparative Responses to International Economic Crises (Ithaca, NY: Cornell University Press, 1986); and Ronald Rogowski, Commerce and Coalitions (Princeton, NJ: Princeton University Press, 1989).

${ }^{19}$ See, for example, Richard F. Doner, "Limits of State Strength: Toward an Institutionalist View of Economic Development," World Politics 44,3 (1992): 398-431; Stephan Haggard, Sylvia Maxfield, and Ben Ross Schneider, "Theories of Business and Business-State Relations," in Business and the State in Developing Countries, ed. Sylvia Maxfield and Ben Ross Schneider (Ithaca, NY: Cornell University Press, 1997): 36-60; and Hector E. Schamis, "Distributional Coalitions and the Politics of Economic Reform in Latin America," World Politics 51,2 (1999): 236-68.

${ }^{20}$ See R. William Liddle, "The Politics of Shared Growth: Some Indonesian Cases," Comparative Politics 19,2 (1987): 127-46; and M. Hadi Soesastro, "The Political Economy of Deregulation in Indonesia," Asian Survey 29,9 (1989): 853-69. 
for sharpening the analysis of politics under communism. ${ }^{21}$ Thus emerged what might be termed the "modified pluralisms" in the study of the New Order political economy.

Modified pluralisms bring together the concept of group competition with some other feature of the New Order political system-traditionally, either its extensive bureaucracy or its top-down political system-to describe a hybrid political system. Examples include "bureaucratic pluralism" as used by Dwight King and Donald Emmerson, ${ }^{22}$ John Bresnan's "managed pluralism," ${ }^{23}$ and Hadi Soesastro and Peter Drysdale's "constrained pluralism." ${ }^{24}$ Bureaucratic pluralism is perhaps the most theoretically developed of these modified pluralisms, drawing on a long theoretical lineage that Emmerson traces to early writings by Juan Linz. ${ }^{25}$ In this way, the modified pluralisms drew from theoretical models that had been first elaborated to understand the postwar authoritarian regimes of southern Europe and Latin America.

These analyses also reveal a fundamental concern with policy as central to political conflict. The analytical focus on policy outcomes was certainly dominated by economic concerns, but material resources and economic interests occupy no special position in the modified pluralist analyses of Indonesia or in the pluralist literature that was evolving at the same time. ${ }^{26}$ That said, the relationship between the modified pluralisms and the broader concept of pluralism (or of, say, bureaucraticauthoritarianism ${ }^{27}$ ) has never been outlined with much precision. ${ }^{28}$ It is not clear if the modified pluralisms are diminished subtypes of pluralism (such as pluralism minus electoral democracy) or proper subtypes of authoritarianism (authoritarian rule plus identifiable group conflict). ${ }^{29}$ In general, the problem hindering the comparative analysis of the New Order regime in pluralist terms has been the difficulty of describing the conceptual features of pluralism that scholars remove when they employ "bureaucratic" and other modifiers. This problem recalls the earlier critiques of pluralism as a theoretical framework without a coherent set of foundational principles upon which all of its adherents or proponents agreed.

\footnotetext{
${ }^{21}$ For a review, see Gabriel A. Almond with Laura Roselle, "Model Fitting in Communist Studies," in $A$ Discipline Divided, ed. G. Almond, pp. 66-116.

${ }^{22}$ Donald K. Emmerson, "Understanding the New Order: Bureaucratic Pluralism in Indonesia," Asian Survey 23,11 (1983): 1220-41; and Dwight Y. King, "Bureaucracy and Implementation of Complex Tasks in Rapidly Developing States," Studies in Comparative and International Development 30,4 (1995/1996): 78-92.

${ }^{23}$ John Bresnan, Managing Indonesia: The Modern Political Economy (New York, NY: Columbia University Press, 1993).

${ }^{24}$ M. Hadi Soesastro and Peter Drysdale, "Survey of Recent Developments," Bulletin of Indonesian Economic Studies 26,3 (1990): 3-44.

${ }^{25}$ Emmerson, "Understanding the New Order," p. 1222; and Juan J. Linz, Totalitarian and Authoritarian Regimes (Boulder, CO: Lynne Rienner, 2000).

${ }^{26}$ Dahl, "Pluralism Revisited."

${ }^{27}$ Guillermo A. O'Donnell, Bureaucratic Authoritarianism: Argentina, 1966-1973 in Comparative Perspective (Berkeley, CA: University of California Press, 1988).

${ }^{28}$ This parallels the general problem of classifying the New Order regime; see Dwight Y. King, "Indonesia's New Order as a Bureaucratic Polity, a Neopatrimonial Regime, or a Bureaucratic Authoritarian Regime: What Difference Does It Make?," in Interpreting Indonesian Politics: Thirteen Contributions to the Debate, ed. Benedict Anderson and Audrey Kahin (Ithaca, NY: Cornell Southeast Asia Program Publications, 1982), pp. 104-16.

${ }^{29}$ On diminished versus proper subtypes, see David Collier and Steven Levitsky, "Democracy with Adjectives: Conceptual Innovation in Comparative Research," World Politics 49,3 (1997): 430-51.
} 
Rescuing pluralism as a tool for understanding Indonesian politics from the analytical morass of slippery definitions and diminished/proper subtypes requires a different strategy than that found in the modified pluralist approach. Rather than describing Indonesian politics as pluralist, modified pluralist, or something elsethereby elaborating the position of the entirety of Indonesian politics within a typological space-the task of pluralism in modern political economy is to provide a tool through which to analyze particular problems in Indonesian politics. That tool is, simply, the analysis of interests and their articulation in the political sphere. The utility of a pluralist approach in one conceptual or empirical domain need not signal its global utility for all questions in Indonesian politics. Proponents of this approach ought to be skeptical of their ability to read interests from observed behavior, or from actors' and groups' economic or social profiles, and will theorize explicitly relationships between interests and particular institutional structures when making claims about the effects of interests on policy or other outcomes. Recalling Lukes's critique of power, critical pluralism will also be sensitive to "recognitional domination," in which the interests of individuals or groups are ascribed to them by external actors, social structures, or state institutions. ${ }^{30}$

Pluralism, then, should not be considered a theory or description of Indonesian politics in the way that modified pluralisms were. It is one framework through which to organize observations about political conflict in Indonesia, and theorize about the origins and consequences of that conflict. Its contribution to the study of material resources and political power is twofold. First, it characterizes the objectives of materially endowed actors. Second, it places material interests alongside non-material interests in order to understand how they interact to shape political action.

Importantly, this is not necessarily an appeal for a more comprehensive or inclusive account of Indonesian politics. For scholars of Indonesian politics who reject oligarchy as a conceptual framework, one strategy for demonstrating the superiority of some alternative conception of Indonesian politics has been to list the facets of Indonesian politics that the concept of oligarchy cannot explain. These are bound to be many, as the oligarchy theorists are clear that there is much that they do not mean to explain-essentially, any source of power that is not material wealth. This "other things matter too" approach is not the strategy adopted here, for it neither addresses the oligarchy approaches on their own terms nor explains the conditions under which material resources do have explanatory power. In what follows, I endeavor to hew closely to the perfectly sensible idea that material resources are necessarily at play in all aspects of Indonesia's political economy, from national macroeconomic policy to local resource conflict.

\section{Oligarchy and Pluralism: Tensions}

Understood as an approach to political conflict rather than a type of political order or system of power relations, pluralism is not incompatible with oligarchy as defined

\footnotetext{
${ }^{30}$ Lukes, Power, p. 120. Lukes illustrates recognitional domination with reference to Martha Nussbaum's analysis of female identity in India, which is defined only in relation to male interests; see Martha C. Nussbaum, Women and Human Development: The Capabilities Approach (New York, NY: Cambridge University Press, 2000).
} 
in Winters's terms as "the politics of wealth defense by materially endowed actors." ${ }^{31}$ Oligarchs may be indifferent to policies or political events that do not affect the security of their material wealth; here, a pluralist lens may clarify what kind of politics follows. Pluralist approaches may explain what exactly the battles among oligarchs are about when oligarchs line up on different sides of a policy debate. Finally, a pluralist analysis could in principle see oligarchs as one group in conflict with one or more other groups, especially in cases of what Winters terms "civil oligarchies," in which oligarchs have surrendered their arms and are constrained by laws. ${ }^{32}$

Robison and Hadiz use a different definition of oligarchy to characterize the Indonesian case. In their analysis, oligarchy is

Any system of government in which virtually all political power is held by a very small number of wealthy ... people who shape public policy primarily to benefit themselves financially through direct subsidies to their agricultural estates or business firms, lucrative government contracts, and protectionist measures aimed at damaging their economic competitors-while displaying little or no concern for the broader interests of the rest of the citizenry. "Oligarchy" is also used as a collective term to denote all the individual members of the small corrupt ruling group in such a system. The term always has a negative or derogatory connotation in both contemporary and classical usage. ${ }^{33}$

This definition is incompatible with conventional pluralism because, in the conventional understanding, interest groups and other collective actors who are not defined by their wealth nevertheless possess and exercise power. Yet it is wholly compatible with the critical pluralism outlined above, just so long as there exists identifiable distributional conflict among the "wealthy ... people" that forms the basis for political action. Without such conflicts, there is nothing for a pluralist to explain. A critical pluralist analysis, in fact, might conclude that what a naïve pluralist would observe to be conflicting interests groups may really be the manifestations of battles among oligarchs and elites that have been strategically "externalized" onto society (a phenomenon familiar to any observer of the orchestrated demo in post-Suharto Indonesia).

Explaining the political consequences of different configurations of power and interest is central to the pluralist tradition. Yet neither oligarchy nor conventional pluralism is capable on its own of making causal claims. The typology of oligarchy advanced by Winters-in which oligarchies vary by degree of fragmentation, the source of coercion, and whether they are wild or tamed-is instructive in this regard.

\footnotetext{
${ }^{31}$ Winters, Oligarchy, p. 7. Elsewhere, Winters and Benjamin Page observe that an oligarchy can exist within a broadly pluralist political landscape, as in the United States. See Jeffrey A. Winters and Benjamin I. Page, "Oligarchy in the United States?," Perspectives on Politics 7,4 (2009): 731-51. Any account, pluralist or otherwise, of Indonesian politics that denies the existence (real or potential) of a particular politics that follows from wealth defense would be, trivially, incompatible with Winters's approach to oligarchy.

${ }^{32}$ While this is true in principle, I have no clear sense of what such an analysis would look like in practice. Winters and Page are skeptical that treating oligarchs as an interest group makes sense; Winters and Page, "Oligarchy?" p. 738.

${ }^{33}$ See Robison and Hadiz, Reorganising Power, pp. 16-17, note 6. The original source is Paul M. Johnson, "Oligarchy," A Glossary of Political Economy Terms, http: / / www.auburn.edu/ johnspm/gloss/oligarchy (accessed February 13, 2013).
} 
There are no claims that emerge from this typology of oligarchies about what different oligarchic types cause. Instead, these are constitutive statements about what oligarchic types are based on theoretically prior claims about how oligarchs relate to one another and to the provision of violence. There are some observations about what oligarchs do as a result of the type of oligarchy in which they find themselves. But causal claims about the consequences of oligarchy for policy or political outcomes cannot be drawn from this typology alone. This weakness, of course, is shared by conventional pluralism.

Robison and Hadiz's understanding of oligarchy similarly does not provide causal explanations for political outcomes. But it is not an elaboration of the concept of oligarchy as a theoretical category, but rather of the practice of oligarchy (as defined by the authors) in Indonesia. This description of the Indonesian case is no less theoretical than that of Winters, but it stresses the historical development of a structure of political power and its changes over time.

However, despite the compatibility of both conceptions of oligarchy and what I have described as critical pluralism, it is not true that oligarchy and pluralism are orthogonal theoretical projects. This makes the relationship between oligarchy and pluralism different than the relationship between oligarchy and democracy, which both Hadiz and Robison and Winters hold to be compatible. ${ }^{34}$ Critical pluralism makes demands on the analysis of oligarchy, political power, and material inequality in Indonesia. For scholars working in the pluralist tradition, any attempt to study politics without reference to policy and its consequences is incomplete. Here, policy is understood simply as "a principle or course of action adopted or proposed as desirable, advantageous, or expedient." ${ }^{35}$ Policy is central to the pluralist tradition because it is the object of political contestation. It can be as broad and substantive as a social democratic party platform, or as narrow and venal as directing a regulator to harass a business competitor. ${ }^{36}$ Policies have direct effects (for example, on the business competitor who is harassed) and indirect effects (for example, on the investment decisions of potential market entrants who anticipate being harassed themselves). In the pluralist tradition, a progressive research program in Indonesian political studies would be one that produces theories of political outcomes and policy choices, and that can explain why policies and outcomes vary across time and space through falsifiable hypotheses derived from these theories.

\footnotetext{
${ }^{34}$ In the conventional understanding, the association between pluralism and democracy is definitional. Dahl is absolutely clear: "all democratic countries are pluralist democracies"; see Robert A. Dahl, Dilemmas of Pluralist Democracy: Autonomy vs. Control (New Haven, CT: Yale University Press, 1982), p. 5. While theoretically important for the pluralist tradition, this point is ultimately of little consequence for the current purposes of characterizing politics in countries marked by vast inequality of material resources. A committed materialist might argue that the associations that are relatively autonomous in pluralist democracies like Indonesia are simply those that lie outside of the interests of oligarchs or economic elites.

${ }^{35}$ This is a standard dictionary definition. "policy, n.1," OED Online (Oxford University Press, December 2012), http: / / www.oed.com/ view / Entry/146842?rskey=uMAZca\&result=1\&isAdvanced=false (accessed February 10, 2013).

${ }^{36}$ Note, further, that policies may be coherent or contradictory; that policies may be pursued by politicians, their supporters, or by segments of society that are entirely disenfranchised; and that policies may even be illegal.
} 
The study of corruption in post-Suharto Indonesia illustrates the differences between typological theory and causal explanation, and, accordingly, the differences between approaches rooted in oligarchy versus the pluralist tradition. Oligarchy theorists have noted that the power of Indonesia's super-wealthy has been "reorganized" rather than reduced since the transition to democracy. ${ }^{37}$ In Winters's typology, Indonesian oligarchy is transforming from a sultanistic oligarchy towards an "untamed ruling oligarchy." ${ }^{38}$ Related observations about the structure of elite politics and political business relations (the term "oligarchy" is not used) in the early post-New Order period were made separately by Andrew MacIntyre and Ross McLeod, both considered to be working in different theoretical traditions than scholars of oligarchy. ${ }^{39}$ Focusing on corruption, each argues that the basic logic of money politics changed after the New Order's demise. MacIntyre and McLeod, however, propose hypotheses to explain how different organizations of elite politics or political business relations affect the overall level and structure of corruption. They imply, following canonical models of the industrial organization of corruption, ${ }^{40}$ that without any mechanism for binding the grasping hands of thousands of lower-level politicians and administrators, bribes in post-Suharto Indonesia are smaller in size than they were during the New Order but more frequent in number. As a consequence, corruption in post-Suharto Indonesia has threatened investment more than corruption under the New Order did, at least at the time that MacIntyre and McLeod were writing. ${ }^{41}$

I am not aware of any test of this hypothesis, and the available evidence supporting it is impressionistic and incomplete, supported by anecdotes and blanket pronouncements of what "everybody knows." However, MacIntyre and McLeod's arguments are consistent with a research program that moves from a descriptive account of the changing organization of money politics to a causal account of its effects on investment in post-Suharto Indonesia. This is an argument that can be falsified, though it is true that no systematic attempt to do so has been initiated to date.

In sum, the points of tension between analytical approaches based on oligarchy and critical pluralism lie not in the conceptualization of oligarchy or in the analytical focus on the social foundations of political conflict, but rather in the focus on policy as the object of political contestation and the development of causal explanations for political outcomes. These tensions are consequential for the study of Indonesian politics. The following section expands on this theme, presenting two topical studies of political conflict in Indonesia in the context of massive inequality in material wealth and political power.

\footnotetext{
${ }^{37}$ Thus the title of Robison and Hadiz, Reorganising Power.

${ }^{38}$ Winters, Oligarchy, p. 181.

${ }^{39}$ Andrew MacIntyre, "Institutions and the Political Economy of Corruption in Developing Countries," paper presented at the "Workshop on Corruption," Stanford University, January 31-February 1, 2003; and Ross H. McLeod, "Soeharto's Indonesia: A Better Class of Corruption," Agenda 7,2 (2000): 99-112. I make no claim that either would be comfortable being labeled as a (critical) pluralist, or even as working in a pluralist tradition or framework. Their insights, however, are wholly compatible with my approach to constructing a pluralist analysis of corruption in Indonesia.

${ }^{40}$ Andrei Shleifer and Robert W. Vishny, "Corruption," Quarterly Journal of Economics 108,3 (1993): $599-617$.

${ }^{41}$ Both authors saw Indonesia's legal system as completely ineffective.
} 


\section{Oligarchy and Pluralism at Work}

To demonstrate that a focus on oligarchy alone occludes fundamental questions of politics and policymaking, I examine here two of the central political issues of the past twenty years of Indonesian history: the economic crisis of 1997-98 and local political economies in decentralized Indonesia. In the case of the crisis, I argue that even ignoring non-material interests entirely, a pluralist approach provides the only theoretical framework that can capture the conflicts concerning policy adjustments within the New Order coalition that set in motion the collapse of the Indonesian economy and, ultimately, of the New Order regime. In the case of decentralization, I show that the effects of material resources on political conflict are always conditional on non-material factors, making it impossible to understand the effects of material inequality in isolation from the conditions under which resources are deployed.

\section{Material Interests, Adjustment Policy, and Regime Change}

By the early 1990s, most analysts of the New Order had come to agree that Suharto, as an individual, wielded extraordinary political power. In characterizing the system of rule over which Suharto presided, scholars of oligarchy draw attention to a tiny cohort of extremely wealthy businessmen (they were nearly all men) whose economic position depended on their close personal relationships with Suharto and who amassed fortunes of truly staggering size. These scholars, like those working in other traditions, identified these wealthy figures as the movers and shakers of the Indonesian economy during the New Order. The personal lives and business empires of figures such as William Soeryadjaya and Liem Sioe Liong, in fact, could be used to chart the evolution of Indonesia's entire political economy. ${ }^{42} \mathrm{~A}$ central argument in Robison and Hadiz is that many of these powerful individuals were remarkably successful in protecting not only their wealth but also their political position during the course of Indonesia's democratic transition, something that the most Pollyannaish analysts of Indonesia's democratic transition might not have expected. For his part, as noted above, Winters argues that the politics of wealth defense in Indonesia is in the process of moving from a sultanistic oligarchy towards an "untamed ruling oligarchy" ${ }^{43}$ in which money is at the core of politics, but in a different way than it had been under the New Order. ${ }^{44}$ The approaches therefore agree that Indonesia oligarchy has changed, but not been eliminated, through democratization.

If interest groups, trade associations, labor groups, and others do not effectively lobby or campaign on enduring issues or coherent platforms, then the conventional pluralist framework of interest group competition is not appropriate for characterizing Indonesian politics, at least at the national level. However, even if analysts stay

\footnotetext{
${ }^{42}$ Marleen Dieleman and Wladimir M. Sachs, "Coevolution of Institutions and Corporations in Emerging Economies: How the Salim Group Morphed into an Institution of Suharto's Crony Regime," Journal of Management Studies 45,7 (2008): 1274-300; and Yuri Sato, “The Astra Group: A Pioneer of Management Modernization in Indonesia," The Developing Economies 34,3 (1996): 247-80.

${ }^{43}$ Winters, Oligarchy, p. 181.

${ }^{44}$ This "less genteel game of bagi-bagi" compares with Aspinall's analysis of the proyek (project); see Edward Aspinall, "A Nation in Fragments: Patronage and Neoliberalism in Contemporary Indonesia," Critical Asian Studies 45,1 (2013): 27-54.
} 
focused on the national level, careful analysis of distributional politics in the pluralist tradition is necessary to understand the most important events in Indonesia's modern history since the consolidation of the New Order in 1971: the collapse of the Indonesian economy in 1997 and of the New Order in 1998.

As I detail elsewhere, the Asian Financial Crisis did not generate a free-for-all among those who would be labeled as oligarchs, nor a unified rejection of Suharto's regime by oligarchs and political and business elites, ${ }^{45}$ nor did it simply disrupt a fundamentally flawed political-economic model. ${ }^{46}$ It generated a specific distributional conflict between two fractions of capital owners: those with fixed and mobile capital. ${ }^{47}$ At the root of the conflict was a disagreement regarding how to adjust to the crisis, featuring two technically incompatible adjustment policy packages with different distributional implications. The group of individuals who would be labeled as oligarchs were one set of actors, divided between the two fractions, but the fractions included more modest business interests as well. Distributional conflict therefore both divided the oligarchs and created common cause between oligarchs and less spectacularly wealthy actors.

This perspective reveals that the manifestly ineffective policy response of the New Order's final year in office was far from irrational or ideological. ${ }^{48}$ Instead, it was fundamentally political-the low politics generated by the oligarchs and small businesses alike trying to avoid going out of business. The problem was of their own making, with firms having become overextended and borrowers having ignored exchange rate risk when obtaining loans denominated in foreign currencies. And the conflict was simple: imposing capital controls was directly contrary to the interests of mobile capital, but the exchange rate peg and expansionary macroeconomic policy stance so desired by local firms rooted in Indonesia would be feasible only with a closed capital account. ${ }^{49}$

\footnotetext{
${ }^{45}$ This is implied by Winters's quote from Rizal Ramli, "Everyone is piling on now and kicking him because they know he's down ..." Winters, Oligarchy, p. 178.

${ }^{46}$ For Robison and Hadiz: "We propose that the crisis eroded the financial and political cement that had papered over a profoundly flawed and vulnerable system wholly reliant on the protection of a corrupt and authoritarian system of state power and an unregulated engagement with volatile global capital markets ..." Robison and Hadiz, Reorganising Power, p. 149.

${ }^{47}$ Thomas B. Pepinsky, "Capital Mobility and Coalitional Politics: Authoritarian Regimes and Economic Adjustment in Southeast Asia," World Politics 60,3 (2008): 438-74.

${ }^{48}$ In an otherwise compelling treatment, Robison and Andrew Rosser mistake the nature of policy conflict during the crisis; see Richard Robison and Andrew Rosser, "Contesting Reform: Indonesia's New Order and the IMF," World Development 26,8 (1998): 1593-609. Rather than a fundamentally ideological conflict between the IMF and "Suharto, the politico-business families, and the major conglomerates" (pp. 1599_ 1603), this was a distributional conflict within the latter about how to escape the crisis without destroying the economic resources of some fraction of capital owners. Robison and Hadiz similarly neglect the basic conflict within Suharto's ruling coalition when describing IMF (International Monetary Fund) programs as "frustrated by resistance from the major politico-business families ..." Robison and Hadiz, Reorganising Power, p. 157. Managing twin currency and banking crises in any emerging economy requires difficult choices about exchange rate and capital account policy. The fact that the IMF mandated a "neoliberal" policy package did not make this policy conflict any more serious than it would have been without the IMF, as the Malaysian experience shows. See Pepinsky, "Capital Mobility."

${ }^{49}$ The cases of Malaysia in 1998 and Chile and Mexico in 1982 demonstrate this solution in action, as well as the distributional politics of such a policy response.
} 
The observation that Indonesia's super-wealthy protected their wealth as much as they could during the crisis conveys precisely no information about the nature of that most central policy battle. The distributional coalitions activated by the currency crisis of 1997 were decidedly not interest groups as conventionally understood, and they did not act as coherent actors that aimed to represent some enduring social or economic interest. Yet political conflict in the final months of the New Order was fundamentally conflict over how to distribute the burden of adjustment across various allies of the regime. I further argue that this conflict not only shaped adjustment policy, it ultimately tore the regime apart, explaining not only the collapse of Suharto's rule but also the manner in which the regime fell. ${ }^{50}$ But even if the end of the New Order was overdetermined-if the "true" cause of its collapse was actually Suharto's senility, the mobilization of civil society opposition and brave protesters, the rightful resistance of key opposition elites, a revolt within the military, a combination of these, or something else altogether-distributional interests are essential for characterizing policy conflict during the crisis. There is no other coherent explanation for why the regime would pretend to be committed to implementing the IMF's adjustment packages, why oligarchs and lower-level business interests would object (and object for the reasons that they did), how the distributional coalitions would emerge to contest both the IMF and the Suharto regime, and why Suharto or any of his closest cronies would care about any of this.

According to scholars working in the oligarchy tradition, the economic crisis led elites and oligarchs to fight among each other and eventually to abandon Suharto, an analysis that papers over the fundamental conflicts within the regime's coalition. Analyses based in the oligarchy tradition also ignore-because they are not equipped to observe-the basic observation that most brutal dictatorships temporarily insulate themselves from global financial markets when facing unanticipated currency and banking crises, using the breathing space to reflate their economies and crush their opponents. ${ }^{51}$ An approach rooted in the pluralist tradition asks, first, what the distributional consequences of different adjustment measures are, and, second, which political coalitions happen to be empowered (for reasons that can be uncovered from the historical evolution of particular regimes). It both explains how adjustment policy battles unfolded in Indonesia, and provides a template for comparative analysis of the Indonesian case, facilitating direct comparison with both Malaysia during the Asian Financial Crisis and certain Latin American dictatorships during the 1980 s debt crisis. $^{52}$

The case of adjustment policy conflict and the collapse of the New Order illustrates the power of distributional politics as a framework for understanding the actions of even the most powerful and wealthy economic actors in Indonesia. I do not conclude from this discussion that a pluralist approach to policy conflict in the New Order's final year requires any fundamental rethinking of the theory of oligarchy as articulated by either Robison and Hadiz or Winters. Instead, the intensely political struggle over

\footnotetext{
${ }^{50}$ Thomas B. Pepinsky, Economic Crises and the Breakdown of Authoritarian Regimes: Indonesia and Malaysia in Comparative Perspective (New York, NY: Cambridge University Press, 2009).

${ }^{51}$ The case of Malaysia after September 1, 1998, is one example. The onset of Malaysia's crackdown against its domestic opposition followed by exactly one day the announcement of capital controls and an exchange rate peg.

${ }^{52}$ Pepinsky, Economic Crises.
} 
adjustment policy during Indonesia's financial crisis reveals the limits of analyses focused on oligarchy for understanding political conflict among Indonesia's most extremely wealthy and powerful citizens.

\section{Material Interests, Decentralization, and Local Politics}

After democratization, decentralization is the second fundamental change to the New Order political economy that occurred after the Asian Financial Crisis. Decentralization has empowered subnational political actors in new ways, and placed new pressures on local politicians to cater to their constituents' demands. The results have been disappointing on a number of fronts: corruption and money politics remains rampant, local reforms have stalled, district governments continue to be ineffective, and other pathologies abound. Hadiz traces most if not all of these pathologies to the basic observation that "predatory" interests at the local level were not disempowered by the collapse of the New Order and the democratization and decentralization that followed. ${ }^{53}$ Just the opposite: regime change in Jakarta generated new pressures for local elites to use the new powers delegated to them to protect their own political and economic interests. Even self-styled reformist outsiders must obey the rules of the game of bagi-bagi (sharing around) as Hadiz and Robison and Winters all comment when discussing the rise of populist reformer Joko Widodo. ${ }^{54}$

Scholars working in many theoretical traditions have concluded that decentralization has not generated the outcomes that its most strident advocates had promised, in some cases providing empirical cases that anticipated the theoretical analyses that draw on oligarchy. ${ }^{55}$ This has been raised in reviews of major critical works on local politics and Indonesian democratization, which have noted that the balance of existing scholarly opinion on democratization and decentralization has always been circumspect in suggesting that the two would produce unambiguously positive outcomes in terms of representation or popular welfare, in Indonesia or anywhere else ${ }^{56}$ So critical political economy does not help much to characterize the disappointing outcomes of Indonesian decentralization. The strong insight offered by a

\footnotetext{
${ }^{53}$ Vedi R. Hadiz, Localising Power in Post-Authoritarian Indonesia: A Southeast Asian Perspective (Stanford, CA: Stanford University Press, 2010).

${ }^{54}$ Vedi R. Hadiz and Richard Robison, "Political Economy and Oligarchy," this volume; and Jeffrey Winters, "Oligarchic Power in Indonesia," this volume.

55 The literature on this topic is now large and developed. Some representative contributions include Iwan Jaya Azis and Maria Monica Wihardja, "Theory of Endogenous Institutions and Evidence from an Indepth Field Study in Indonesia," Economics and Finance in Indonesia 58,3 (2010): 30-334; Michael Buehler, "Decentralisation and Local Democracy in Indonesia: The Marginalisation of the Public Sphere," in Problems of Democratisation in Indonesia: Elections, Institutions and Society, ed. Edward Aspinall and Marcus Mietzner (Singapore: Institute of Southeast Asian Studies, 2010), pp. 267-85; Blane Lewis, "Tax and Charge Creation by Regional Governments under Fiscal Decentralization: Estimates and Explanations," Bulletin of Indonesian Economic Studies 39,2 (2003): 177-92; Michael S. Malley, "New Rules, Old Structures, and the Limits of Democratic Decentralisation," in Local Power and Politics in Indonesia: Decentralisation and Democratisation, ed. Edward Aspinall and Greg Fealy (Singapore: Institute of Southeast Asian Studies, 2003), pp. 102-16; and Thomas B. Pepinsky and Maria M. Wihardja, "Decentralization and Economic Performance in Indonesia," Journal of East Asian Studies 11,3 (2011): 337-71.

${ }^{56}$ Michael Buehler, "Review of Nankyung Choi, Local Politics in Indonesia: Pathways to Power," Publius: The Journal of Federalism 42,4 (2012): e9; and Marcus Mietzner, "Review of Vedi R. Hadiz, Localising Power in Post-Authoritarian Indonesia: A Southeast Asia Perspective," South East Asia Research 19,3 (2011): 669-72.
} 
critical analysis of wealth defense and predatory elites, rather, is that institutional reforms may change the character of local politics without disembedding the local elites who occupied positions of power directly prior to the reforms. Those local elites "have a large stake in the localisation of power, thus in decentralisation and democracy," ${ }^{57}$ yet not in popular representation or accountability. I believe that even the most skeptical analysts of Indonesian decentralization failed to anticipate the importance of this argument for Indonesia today.

A conventional pluralist analysis of local politics as competition among interest groups has not been shown to offer much empirical traction in analyses of important topics in Indonesian local politics. However, recalling that a critical pluralism should question why interests are or are not articulated, should move beyond one- and twodimensional analyses of power and interest, and take history and social structures seriously, then pluralism offers the natural framework through which to build an account of how local politics varies across Indonesia and why this matters.

Begin first with the problem of interest articulation. Conventional pluralist analyses in Indonesia fail because local politics in Indonesia generally does not provide a forum for the articulation of group interests, or of anything resembling the public interest (assuming such a thing exists). However, some interests are articulated-and, indeed, represented-in some contexts. Why? One possibility is that interests are represented when the local political and economic elite has a particular structure, such as what Christian von Lübke has labeled a "contested oligarchy," in which local elites compete, but not too much, allowing some private interests to seek representation. ${ }^{58}$ Another possible explanation is that local elites can choose to seek political support from different segments of society, sometimes reaching out to the poor and serving as effective representatives. ${ }^{59}$ Alternatively, Ryan Tans argues that despite the ubiquity of money politics in Indonesian local elections, it is possible to identify different types of political coalitions in various local contexts: mafias, machines, and mobilizing coalitions. ${ }^{60}$ Mobilizing coalitions are most conducive to interest group representation in the pluralist mode, and machines are more likely to provide public goods than are mafias. Tans proposes that different coalitions emerge in different circumstances depending on the resources, both material and non-material, that are available to local politicians. Following this approach, any analysis of money politics that ignores nonmonetary resources at the disposal of local politicians, or the goals for which monetary resources are used, will fail to account for this variation. ${ }^{61}$

\footnotetext{
${ }^{57}$ Hadiz, Localising Power, p. 88.

${ }^{58}$ Christian von Lübke, "Striking the Right Balance: Economic Concentration and Local Government Performance in Indonesia and the Philippines," European Journal of East Asian Studies 11,1 (2012): 17-44. Von Lübke's use of "oligarchy" as the basis for an analytical framework does not correspond to either Winters's or Robison and Hadiz's use of the term.

${ }^{59}$ Andrew Rosser, Ian Wilson, and Priyambudi Sulistiyanto, "Leaders, Elites, and Coalitions: The Politics of Free Public Services in Decentralised Indonesia," Developmental Leadership Program Research Paper 16, 2011.

${ }^{60}$ Ryan Tans, Mobilizing Resources, Building Coalitions: Local Power in Indonesia (Honolulu, HI: East West Center, 2012).

${ }^{61}$ Ibid., pp. 56-57.
} 
The next step in building a progressive research program from Tans's analysis is to delineate the consequences of coalition types for policymaking and political outcomes. For example, it could be that mobilizing coalitions secure more public goods than do mafias or machines, and that flows of financial resources to constituents are combined with mobilizational efforts that recognize and/or reify existing group identities and interests. Such an analysis in the pluralist tradition would argue that the determinants of interest articulation in Indonesian local politics are only rendered visible by taking into account the interaction of material and non-material resources available to local politicians. The concept of interaction is critical: it rejects the presumptive defense by a materialist scholar that non-material resources are outside of his/her theory's explanatory scope. Instead, the importance of material resources always depends on non-material factors. By specifying ex ante the determinants of coalition types and the consequences of coalitional politics for policies and political outcomes, moreover, such accounts can easily be falsified, and readily subject to critical comparative analysis.

All pluralist analyses take history and social structure seriously, but a critical pluralism should use history and structure to help understand why interest articulation fails. In the context of decentralized Indonesia, this means understanding the legacies of authoritarian rule, and the ways in which these shape the resources and strategies available to local political actors. Michael Buehler has observed that reform and accountability have been hamstrung by the simple fact that old elites continue to dominate local politics in the era of decentralization. ${ }^{62}$ This fact is compatible with an oligarchic approach to local political economies, but it is not demonstrative of any theory. It might instead reflect the continuity of the Indonesian state, ${ }^{63}$ which, to use Benedict Anderson's colorful language, has continued to "excrete ... personnel in a continuous, steady process, often over long periods of time." ${ }^{64}$ Further complicating this analysis is the extraordinary heterogeneity among New Order elites, a category that is descriptively simple but conceptually broad and unwieldy precisely because the New Order regime so pervaded the public sphere and associational life. This renders nearly all post-New Order elites tainted by their association with the New Order regime, regardless of their backgrounds or interests or resources or actions in the postSuharto era. ${ }^{65}$

The pluralist approach recognizes that the presence of New Order holdovers in local elections does not convey much information about what they do or how their presence affects local politics or policy. It may be that the New Order holdovers are unresponsive to the very notion of interest articulation because they were socialized under an essentially corporatist model of interest management. It may be that New Order holdovers have differential access to material resources, which frees them from

\footnotetext{
${ }^{62}$ On the political and administrative backgrounds of candidates for provincial elections, see Buehler, "Decentralisation and Local Democracy"; and Marcus Mietzner, "Local Democracy: Old Elites are Still in Power, but Direct Elections Now Give Voters a Choice," Inside Indonesia 17 (2006): 17-18. Based on incomplete data, the pattern appears to be similar in district elections; Michael Buehler, personal communication, January 2013.

${ }^{63}$ Buehler, "Decentralisation and Local Democracy."

${ }^{64}$ Benedict R. O'G. Anderson, “Old State, New Society: Indonesia's New Order in Comparative Historical Perspective," Journal of Asian Studies 42,3 (1983): 477-96, p. 478.

${ }^{65}$ See also Tans, Mobilizing Resources, pp. 56-57.
} 
the need to represent interests in order to ensure their political survival. It may be that some kinds of New Order holdovers do not act in the same way: lifetime politicians may be different from bureaucrats-turned-politicians. These arguments have different implications for variation in local governance across regions, and they have different implications for the prospects for reform. Each of these possibilities recognizes the New Order's historical legacy as being fundamental to understanding contemporary local politics. None follows from the oligarchic approach, or from the observation that decentralization reforms did not themselves purge New Order elites from local politics.

The final directive for a critical pluralist analysis of local politics in decentralized Indonesia is to transcend one- and two-dimensional conceptions of power. Lukes's third dimension of power is the power to shape how others understand their own interests, which is important for pluralist analyses because it rejects the assumption that interests are "real" even if believed to be so by those who claim to be acting upon them. This argument has methodological consequences for any analysis of power and political conflict, applying equally to pluralism as to any materialist approach to social analysis, oligarchy included ${ }^{66}$ For a pluralist analysis, the important challenge is that the mechanism of interest articulation may be broken through the purposive actions of oligarchs and elites, who may not act in the direct sense, by smashing unions or imprisoning activists and other movement entrepreneurs, but, more indirectly, by creating the conditions of domination (ideological or structural) that ensure that those groups that might form common interest associations do not believe it possible or desirable to do so. ${ }^{67}$

This phenomenon has long been a concern for critical political economists-it is at the heart of long debates about ideological domination and class conflict in capitalist democracies $^{68}$-and a critical pluralism must take it seriously. Yet critical pluralism is a framework for social explanation, and so when applied to Indonesia, the central endeavor is to theorize the application of power (in all its dimensions) in a way that can explain the variation across time and space in interest articulation. This task can be illustrated in the context of natural resource extraction in the era of decentralization. The exploitation of natural resources by oligarchs is common throughout the

\footnotetext{
${ }^{66}$ The Lukes critique reveals a subtle distinction between Winters's and Hadiz and Robison's understanding of power and interest. Winters explicitly understands power in terms of the "power resources" approach; see Winters, Oligarchy, p. 6. This approach intends to transcend debates over the nature of power rooted in the behavioralist tradition, such that the third dimension of power is simply an "indirect strateg[y] for the rational deployment of power resources ..." Walter Korpi, "Power Resources Approach vs. Action and Conflict: On Causal and Intentional Explanations in the Study of Power," Sociological Theory 3,2 (1985): 41. However, the power resources approach makes clear and direct causal claims about the relationship between the strength of the Left and outcomes of interest such as the development of the welfare state; see Walter Korpi, "The Power Resources Approach," in The Welfare State Reader, ed. Christopher Pierson and Francis G. Castles (Cambridge: Polity Press, 2006), pp. 76-88. In fact, one logical implication of the power resources approach is that it is not possible to study the power of one type of actor in isolation, for outcomes depend on the relative distribution of power among actors (for Korpi: classes). Hadiz and Robison, unlike Winters, make no appeal to power resources theory.

${ }^{67}$ Of course, the entire point of the Lukes critique is that those latent interests can never be observed, making the task of interest attribution (like the concept of power) an "essentially contested" one; Lukes, Power, pp. 124, 44-51.

${ }^{68}$ Antonio Gramsci, Selections from the Prison Notebooks, trans. Quintin Hoare and Geoffrey Nowell Smith (New York, NY: International Publishers, 1971).
} 
Indonesian archipelago. Yet, despite the common interest of oligarchs in discouraging (or suppressing, or eliminating) local resistance to resource exploitation, the local politics of resistance varies in readily apparent ways. Resistance to forest destruction and plantation development in Papua embraces a language of colonial occupation and common armed struggle that is absent in Kalimantan.$^{69}$ For the resource extractors, this necessitates a range of different practices in Papua-even if violence, coercion, bribery, and domination are always present in some form in both contexts. The reasons for the differences between Papua and Kalimantan in this case are obvious. The theoretical point is that any critical analysis of resource extraction in contemporary Indonesia cannot be restricted to the interests of economic elites or oligarchs alone. Powerful economic actors with unparalleled wealth and material resources will attempt to shape local communities' understandings of their own interests, but the strategies that they must pursue to do so will vary predictably. That inquiry is squarely within the ambit of the pluralist tradition.

No one working in the oligarchic tradition would deny that there is important variation in politics and policymaking across local contexts in Indonesia. Hadiz has himself analyzed how local politics has developed in very different districts. Yet neither that analysis nor the theoretical apparatus of oligarchy provides a framework for building explanations for why or how politics varies. The historicist observation that politics varies as a result of local conditions is, of course, not falsifiable when so articulated. It is also imprecise. Which factors, under what conditions, explain what kinds of variation in local politics, with what kinds of consequences? ${ }^{70}$ Analyses following the pluralist tradition should certainly not embrace a conventional pluralist sociology that defines local politics as simple interest group competition, yet they are well placed to build accounts that can answer these questions.

\section{Concluding Remarks}

This essay has traced the development of pluralism as a framework for comparative analysis of political conflict in Indonesia. Mindful of the many trenchant critiques of the conventional pluralism of mid-twentieth-century North Atlantic political science, it has shown that the pluralist tradition has been largely abandoned as a grand theoretical project or paradigm in comparative politics, but that the tradition

\footnotetext{
${ }^{69}$ For overviews, compare Longgena Ginting and Oliver Pye, "Resisting Agribusiness Development: The Merauke Integrated Food and Energy Estate in West Papua, Indonesia," ASEAS-Austrian Journal of SouthEast Asian Studies 6,1 (2013): 160-82; and Leslie Potter, "Dayak Resistance to Oil Palm Plantations in West Kalimantan, Indonesia," presented at the Seventeenth Biennial Conference of the Asian Studies Association of Australia, Melbourne, July 1-3, 2008, available at http:/ / artsonline.monash. edu.au/ mai/ files/2012/07/lesleypotter.pdf.

${ }^{70}$ One interesting contrast that is richly described, but not theorized explicitly, is in the different political success in East Java and North Sumatra of various thugs and goons whose power dates to the New Order period. In East Java, the "New Order's former enforcers have notably thrived less in their forays into local politics than their counterparts in North Sumatra." Hadiz, Localising Power, p. 116. Some explanations for the relative failure and success of various candidates proposed in this discussion include the traditional strength of Nahdlatul Ulama in East Java (which alters the nature of competition among local thugs by changing the balance of power among paramilitary groups), different histories of youth gangs in Medan versus Surabaya, and different kinds of military involvement in the criminal underworld; see ibid., pp. 133-42 and especially pp. 139-40.
} 
survives in the analysis of distributional politics. It has further argued that a critical pluralism provides a useful framework for understanding Indonesian politics, even recognizing the striking inequality of material wealth and political power that characterize Indonesia in the post-Suharto era. This argument rejects the typological theorizing of what I have called the "modified pluralisms" of New Order political economy, and places particular emphasis on causal explanation as a central endeavor for Indonesian political studies.

This argument is a challenge to approaches to Indonesian politics that emphasize oligarchy as the central analytical framework. To reiterate the points of tension elaborated above, the challenge is not to Winters's definition of oligarchy as the politics of wealth defense and his conceptualization of how oligarchy varies across time and space, or to Hadiz and Robison's central insight that powerful elites have survived Indonesia's democratization and decentralization and harnessed new institutional arrangements to protect their interests. Rather, critical pluralism challenges the explanatory capacity of these frameworks. In reviewing basic issues confronting scholars of material wealth and political conflict in contemporary Indonesia-the 199798 financial meltdown and subsequent collapse of the New Order, money politics and elite continuity in local elections, the exploitation of natural resources, and so forth-I have shown the limits of the oligarchy approach as a framework of analysis and the utility of a critical pluralist approach. These topical areas are precisely those in which an approach based on oligarchy, which is tightly attuned to the effects of material wealth (and its extraordinarily uneven distribution) on Indonesian politics, should be most useful. That oligarchy does not provide the analytical framework to make sense of these problems should be seen as a challenge to those who rely on oligarchy as a focal lens when seeking to understand the Indonesian case. It also has clear implications for the comparative utility of the oligarchy theses.

Critical pluralism does not only challenge oligarchy by providing competing explanations-derived from a close attention to policy as the fundamental object of contestation-for fundamental issues in Indonesian politics. Critical pluralism also embodies a competing practice of knowledge production in which the task of causal explanation is a natural complement to theoretically informed description and conceptual development. Causal explanations require theories that link causal variables to outcomes of interest under properly delineated scope conditions, and which produce arguments that are subject to falsification. In this sense, the critical pluralism I have described in this essay contains a prescriptive statement about what the scientific analysis of power, conflict, and material inequality in Indonesia ought to become. It is not just that critical pluralism interprets Indonesian politics differently than do other approaches. Rather, the study of Indonesian politics must follow broader disciplinary advances in the social sciences, and adopt a more sophisticated toolkit for adjudicating among competing approaches and perspectives.

This conclusion should not obscure the commonalities between the pluralist tradition and oligarchic approaches. Indeed, I have argued elsewhere that the critical political economy approach of Hadiz, Robison, and others in the Murdoch school shares a basic insight with the most rationalist approaches to institutions in political 
science. ${ }^{71}$ That insight is that interests, not institutions, lie at the root of any coherent explanation of politics and policymaking. A progressive research program on the social foundations of Indonesian political economy will build on this common perspective on the root origins of political conflict. It will also take seriously the task of constructing explanations that can demonstrate the utility of interest-based explanations for capturing the great variation in the nature of political conflict and policy outcomes in unequal societies, such as Indonesia's.

${ }^{71}$ Thomas B. Pepinsky, "The Institutional Turn in Comparative Authoritarianism," British Journal of Political Science (forthcoming 2013). A previous version of that essay circulated under the title "Rochester and Murdoch in Kuala Lumpur." Compare this to the critique of naïve institutionalism in Vedi R. Hadiz, "Decentralization and Democracy in Indonesia: A Critique of Neo-Institutionalist Perspectives,"

Development and Change 35,4 (2004): 697-718. 